\title{
Pengaruh Bi 7 Day (Reverse) Repo Rate, Dana Pihak Ketiga, Capital Adequacy Ratio Dan Financing To Deposit Ratio Terhadap Pembiayaan Murabahah Di Bank Syariah (Studi Pada Pt. Bank Muamalat Indonesia Tbk)
}

\author{
Nurjannah ${ }^{1}$ Wahyudin Maguni ${ }^{2}$ Muhammad Imran $^{3}$ \\ Abdul Wahid Mongkito ${ }^{4}$ Nita Lestari ${ }^{5}$
}

\author{
Agama Islam Negeri (IAIN) Kendari ${ }^{1234}$ \\ Jln. Sultan Qaimuddin No. 17 Kelurahan Baruga-Kota Kendari Telp/Fax (0401) 3193710 \\ E-mail: nurjannah@iainkendari.ac.id ${ }^{1}$, wmaguni@yahoo.com², muhimran@iainkendari.ac.id ${ }^{3}$, \\ wahidmongkito@iainkendari.ac.id ${ }^{4}$
}

\begin{abstract}
Abstrak
Penelitian ini bertujuan untuk mengetahui bagaimana pengaruh Suku Bunga, Dana Pihak Ketiga, dan Capital Adequacy Ratio terhadap Pembiaayan Murabahah di Bank Syariah khususnya pada PT Bank Muamalat Indonesia Tbk tahun 2012 sampai 2019 secara parsial maupun simultan. Populasi dalam penelitian ini adalah laporan keungan Bank Muamalat. Sehingga sampel yang diambil adalah laporan keuangan triwulanan Bank Muamalat periode 2012-2019. Penelitian ini menggunakan metode kuantitatif. Teknik pengumpulan data yaitu dokumentasi. Analisis data yang dilakukan yaitu teknik analisis regresi linear berganda. Dengan patokan pengambilan keputusan adalah 0,05 . Hasil penelitian menunjukan bahwa variabel Suku Bunga tidak berpengaruh secara signifikan terhadap Pembiayaan Murabahah, dilihat dari output olah data analisis regresi linear berganda diperoleh nilai koefisien regresi sebesar 0,015. Selanjutnya dilakukan Uji Parsial (Uji t) diperoleh nilai statistik uji t sebesar 0,127 dengan nilai signifikan sebesar 0,900 yang dimana 0,900 lebih lemah dari 0,05. Variabel Dana Pihak Ketiga berpengaruh secara signifikan terhadap Pembiayaan Murabahah, dilihat dari output olah data analisis regresi linear berganda diperoleh nilai koefisien regresi sebesar 0,763 . Selanjutnya dilakukan uji persial yakni nilai statistik uji t sebesar 6,867 dengan nilai signifikan sebesar 0,000 yang dimana 0,000 lebih kuat dari 0,05. Sedangkan pada variabel Capital Adequacy Ratio tidak berpengaruh secara signifikan terhadap Pembiayaan Murabahah, dilihat dari output olah data analisis regresi linear berganda diperoleh nilai koefisien regresi sebesar 0,223 . Selanjutnya dilakukan uji persial yakni nilai statistik uji t sebesar 1,898 dengan nilai signifikan 0,068 yang dimana 0,068 lebih lemah 0,05 .
\end{abstract}

Kata Kunci: Suku Bunga, Dana Pihak Ketiga, Capital Adequacy Ratio, PembiayaanMurabahah 
Volume 03 Nomor 012021 : page 49-63

p-ISSN: 2686-262X e-ISSN : 2685-9300

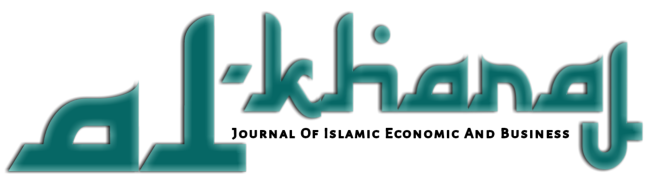

\section{Abstract}

This study aims to determine how the influence of Interest Rates, Third Party Funds, and Capital Adequacy Ratio on Murabahah Financing in Islamic Banks, especially at PT Bank Muamalat Indonesia Tbk from 2012 to 2019 partially or simultaneously. The population in this study is the Bank Muamalat financial report. So that the sample taken is the quarterly financial statements of Bank Muamalat for the period 2012-2019. This research uses quantitative methods. The data collection technique is documentation. The data analysis used is multiple linear regression analysis technique. With the standard of decision making is

0.05 . The results showed that the interest rate variable did not have a significant effect on Murabahah Financing, seen from the output of multiple linear regression analysis data, the regression coefficient value was 0.015. Furthermore, the partial test ( $t$ test) was carried out and the t test statistic value was 0.127 with a significant value of 0.900, which is 0.900 weaker than 0.05. The Third Party Funds variable has a significant effect on Murabahah Financing, seen from the output of multiple linear regression analysis, the regression coefficient value is 0.763 . Furthermore, the partial test was carried out, namely the t-test statistical value of 6.867 with a significant value of 0.000, which is 0.000 which is stronger than 0.05. Whereas the Capital Adequacy Ratio variable does not have a significant effect on Murabahah Financing, seen from the output of multiple linear regression analysis data, the regression coefficient value is 0.223 . Furthermore, the partial test was carried out, namely the t-test statistical value was 1.898 with a significant value of 0.068 , where 0.068 was 0.05 weaker.

Keywords: Interest Rates, Third Party Funds, Capital Adequacy Ratio, Murabahah Financing 


\section{Pendahuluan}

Perbankan Syariah merupakan salah satu instansi yang bergerak pada bidang keuangan yang berbasis syariah. Eksistensi Bank Umum Syariah pada awalnya dilandasi oleh ketentuan UU No 7 Tahun 1992 setelah itu dialihkan ke UU No 10 Tahun 1998 yang membahas Perbankan. Di tahun 2008 dibuatlah undang-undang tersendiri untuk perbankan syariah, yang dimana undang-undang. tersebut adalah UU No 21 Tahun 2008 tentang Perbankan Syariah. Perbankan diatur berdasarkan ajaran syariat Islam dalam perundangundangan tahun 2008 tersebut. Lembaga Keuangan didefinisikan oleh Kasmir dalam buku Andri Soemitro (2009:28) yang diberi judul Bank dan Lembaga Keuangan Syariah yaitu semua instansi yang beroperasi pada bidang keuangan, menghimpun dana, menyalurkan dana atau kedua-duanya. Pada perbankan syariah memiliki produk- produk yang ditawarkan kepada masyarakat yang salah satunya yaitu pembiayaan Murabahah. Pembiayaan Murabahah ini merupakan produk perbankan syariah yang tergolong besar digunakan oleh perbankan syariah dalam menjalankan kegiatan usahanya. Ashraf Usmani mengatakan bahwa murabahah menempati sebanyak $66 \%$ dari semua transaksi investasi bank-bank syariah di dunia. Sementara itu Maulana Taqi Usmani memprediksi lebih dari 80\% produk..investasi serta pembiayaan dari BUS dan UUS di Indonesia menggunakan transaksi pembiayaan murabahah (Sjahdein, 2014:190). Pembiayaan atau kredit yang dalam perbankan syariah haruslah memegang teguh pada keyakinan atau prinsip ajaran islam begitupun dalam menjalankan kegiatan usaha yang lain, hal tersebut masuk dalam UU No. 10 tahun 1998, pada pasal 29 ayat 3, sehingga dalam menjalankan usahanya bank syariah harus melakukan hal-hal yang tidak dapat merugikan bank serta kepentingan masyarakat yang telah mempercayakan dananya kepada bank. Sehingga ketika BUS melakukan transaksi pembiayaan, BUS harus memperhatikan dan mempertimbangkan faktor-faktor yang mempengaruhi pembiayaan. Pada penelitian ini, penulis menduga Suku Bunga, Dana Pihak 
Ketiga (DPK), dan Capital Adequacy Ratio (CAR) merupakan penyebab yang dapat mempengaruhi pembiayaan khususnya pada transaksi murabahah. Dari uraian penjelasan tersebut, maka penulis ingin mengetahui lebih dalam lagi sehingga permasalahan dalam penelitian ini yaitu apakah Suku Bunga, Dana Pihak Ketiga, Capital Adequacy Ratio berpengaruh secara parsial maupun simultan terhadap Pembiayaan Murabah. Sehingga tujuan dari penelitian ini yaitu dapat menemukan jawaban dari permasalahan tersebut.

\section{Metodologi Penelitian}

Pengujian ini menggunakan model regresi linier berganda. Dimana uji tersebut menggunakan uji $\mathrm{F}$ dan uji-t yang dilakukan untuk membuktikan apakah terdapat pengaruh secara simultan dan parsial yang signifikan antara Suku Bunga, Dana Pihak Ketiga dan Capital Adequacy Ratio terhadap Pembiayaan Murabahah. Penelitian yang penulis lakukan ini merupakan penelitian yang bersifat kuantitatif, yaitu penelitian ilmiah yang logis terhadap setiap komponen dan fakta serta factor dan juga hubungannya. Lokasi penelitian adalah tempat atau objek untuk diadakan suatu penelitian. Adapun tempat pelaksanaan penelitian ini adalah PT. Bank Muamalat Indonesia Tbk. Populasi merupakan semua objek atau individu yang akan dipelajari, mempunyai ciri tertentu, jelas serta lengkap (Arifin, 2008: 69). Populasi dalam penelitian ini yaitu laporan keuangan PT. Bank Muamalat Indonesia Tbk.

Sampel merupakan partikel dari populasi yang dipilih dengan cara tertentu yang mewakili ciri-ciri, jelas serta lengkap yang dianggap..mewakili populasi tersebut. Pengambilan sampel dilakukan dengan cara non probability sampling dengan metode purposive sampling yaitu pengambilan sampel dari suatu populasi berdasarkan kriteria tertentu. Sampel dalam penelitian ini adalah Laporan Keuangan Triwulanan PT Bank Muamalat Indonesia Tbk periode Maret 2012 sampai dengan September 2019 yang berjumlah 31 data. Kriteria sampel yang digunakan dalam penelitian ini adalah laporan 
Volume 03 Nomor 012021 : page 49-63

p-ISSN: $2686-262 X$ e-ISSN : 2685-9300

DOI : 10.24256

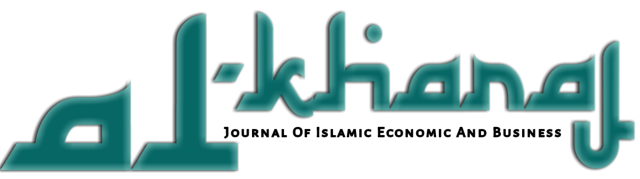

keuangan telah memenuhi standar PSAK dan ketentuan Bank Indonesia serta Surat Edaran Bank Indonesia.

\section{Hasil dan Pembahasan}

Dalam pengolahan data pada penelitian ini menggunakan SPSS sehingga hasil dari output SPSS yang di analisis yaitu Berdasarkan hasil penelitian Suku Bunga memiliki pengaruh positf dan tidak signifikan terhadap Pembiayaan Murabahah. Hal ini berarti semakin besarnya Suku Bunga tidak akan menjadi tolak ukur atau patokan nilai Pembiayaan Murabahah di PT Bank Muamalat Indonesia Tbk.

Berdasarkan hasil analisis regresi linier berganda diperoleh variabel Suku Bunga berpengaruh positif terhadap Pembiayaan Murabahah dengan koefisien regresi sebesar 0,015. Koefisien regresi ini menunjukan bahwa apabila terdapat kenaikan 1 kali pada variabel Suku Bunga dan variabel yang lain dianggap tetap atau sama dengan 0 , maka akan terjadi peningkatan pada variabel Y sebesar 0,015 atau setara dengan 1,5\%.

Pengujian hipotesis secara persial (uji t), didapat hasil bahwa variabel bebas Suku Bunga tidak berpengaruh secara signifikan terhadap Pembiayaan Murabahah. Hal tersebut dapat diketahui dari statistik uji t sebesar 0,127 dengan nilai signifikansi sebesar 0,900 yang dimana nilai Signifikansi ini lebih besar dari nilai pengambilan keputusan pada uji t yaitu sebesar 0,05. Dengan demikian hasil analisis regresi ini menunjukan bahwa Suku Bunga di Bank Muamalat tidak menjadi patokan dalam penetapan margin pada Pembiayaan Murabahah.

Penelitian ini mendukung penelitian Astri Arumdhani, tahun 2012 ini berjudul "Pengaruh Pembiayaan Murabahah dan Tingkat Suku Bunga BI terhadap Pendapatan Margin Murabahah pada PT Bank Syariah Mandiri”. Dari penelitiannya menyatakan bahwa tingkat Suku Bunga BI tidak berpengaruh signifikan terhadap Margin Murabahah. 
Hasil penelitian ini berbeda dengan hasil penelitian yang dilakukan oleh Supandi Rahman, tahun 2015 dalam skripsi yang berjudul "Pengaruh Tingkat Inflasi dan Suku Bunga Konvensional terhadap Pembiayaan Murabahah pada Bank Syariah di Indonesia”. Dari penelitiannya dinyatakan bahwa Suku Bunga memiliki pengaruh positif dan signifikan terhadap permintaan Pembiayaan Murabahah.

BI Rate dan BI 7 Day RR Rate sebagai suku bunga acuan yang di tetapkan oleh Bank Indonesia digunakan sebagai acuan penetapan keuntungan kredit yang biasa digunakan oleh Bank Konvensional. Suku Bunga yang berpengaruh positif namun tidak berpengaruh secara signifikan terhadap Pembiayaan Murabahah pada Bank Muamalat dalam penelitian ini dapat disebabkan karena Bank Muamalat sebagai salah satu bank syariah di Indonesia tidak menggunakan Suku Bunga sebagai acuan dalam penetapan margin melainkan menggunakan sistem bagi hasil. Sebagaimana hakikatnya bahwa bank syariah menggunakan sistem bagi hasil dan bebas dari bunga bank (riba).

\section{Hasil Uji Regresi Linear Berganda}

\begin{tabular}{|c|c|c|c|c|c|}
\hline \multicolumn{6}{|l|}{ Coefficients $^{a}$} \\
\hline \multirow[t]{2}{*}{ Model } & \multicolumn{2}{|c|}{$\begin{array}{l}\text { Unstandardized } \\
\text { Coefficients }\end{array}$} & \multirow{2}{*}{\begin{tabular}{|l}
$\begin{array}{l}\text { Standardized } \\
\text { Coefficients }\end{array}$ \\
Beta
\end{tabular}} & \multirow[t]{2}{*}{$\mathrm{t}$} & \multirow[t]{2}{*}{ Sig. } \\
\hline & B & Std. Error & & & \\
\hline (Constant) & -.062 & 8.395 & & -.007 & .994 \\
\hline TSB & .015 & .117 & .015 & .127 & .900 \\
\hline TDPK & .763 & .111 & .763 & 6.867 & .000 \\
\hline TCAR & .223 & .118 & .223 & 1.898 & .068 \\
\hline
\end{tabular}

a. Dependent Variable: TPM

Sumber: Hasil Uji SPSS, Tahun 2020

Berdasarkan hasil penelitian Dana Pihak Ketiga memiliki pengaruh positf dan signifikan terhadap Pembiayaan Murabahah. Hal ini berarti semakin besarnya nilai Dana Pihak Ketiga maka besar pula nilai penyaluran Pembiayaan Murabahah di PT Bank Muamalat Indonesia Tbk. 
Berdasarkan hasil analisis regresi linier berganda diperoleh variabel Dana Pihak Ketiga berpengaruh positif terhadap Pembiayaan Murabahah dengan koefisien regresi sebesar 0,763. Koefisien regresi ini menunjukan bahwa apabila terdapat kenaikan 1 kali pada variabel Dana Pihak Ketiga dan variabel yang lain dianggap tetap atau sama dengan 0, maka akan terjadi peningkatan pada variabel Y sebesar 0,763 atau setara dengan 7,63\%.

Pengujian hipotesis secara persial (uji t), didapat hasil bahwa variabel bebas Dana Pihak Ketiga berpengaruh secara signifikan terhadap Pembiayaan Murabahah. Hal tersebut dapat diketahui dari statistik uji t sebesar 6,867 dengan nilai signifikansi sebesar 0,000 yang dimana nilai Signifikansi ini lebih kecil dari nilai pengambilan keputusan pada uji t yaitu sebesar 0,05. Dengan demikian hasil analisis regresi ini menunjukan bahwa Dana Pihak Ketiga di Bank Muamalat merupakan salah satu faktor yang berpengaruh dalam Pembiayaan Murabahah.

Penelitian ini mendukung penelitian Ferial Nurbaya pada tahun 2013 penelitian ini berjudul "Analisis Pengaruh CAR, ROA, FDR, dan Dana Pihak Ketiga (DPK) terhadap Pembiayaan Murabahah Periode Maret 2001 - Desember 2009”. Dari penelitiannya menyatakan bahwa DPK memiliki pengaruh yang positif dan signifikan terhadap pembiayaan murabahah.

Dana Pihak Ketiga (DPK) adalah dana yang berasal dari masyarakat merupakan sumber dana terbesar yang paling diandalkan oleh bank yang berupa deposito, tabungan dan giro. Kegiatan bank setelah menghimpun dana dari masyarakat luas adalah menyalurkan kembali dana tersebut kepada masyarakat yang membutuhkannya, dalam bentuk pinjaman atau lebih dikenal dengan pembiayaan.

Berdasarkan hasil penelitian Capital Adequacy Ratio memiliki pengaruh positf dan tidak signifikan terhadap Pembiayaan Murabahah. Hal ini berarti semakin besarnya nilai Capital Adequacy Ratio maka tidak ada pengaruh terhadap penyaluran Pembiayaan 
Murabahah di PT Bank Muamalat Indonesia Tbk.

Berdasarkan hasil analisis regresi linier berganda diperoleh variabel Capital Adequacy Ratio berpengaruh positif terhadap Pembiayaan Murabahah dengan koefisien regresi sebesar 0,223 . Koefisien regresi ini menunjukan bahwa apabila terdapat kenaikan 1 kali pada variabel Capital Adequacy Ratio dan variabel yang lain dianggap tetap atau sama dengan 0 , maka akan terjadi peningkatan pada variabel $\mathrm{Y}$ sebesar 0,223 atau setara dengan $2,23 \%$.

Pengujian hipotesis secara persial (uji t), didapat hasil bahwa variabel bebas Capital Adequacy Ratio tidak berpengaruh secara signifikan terhadap Pembiayaan Murabahah. Hal tersebut dapat diketahui dari statistik uji t sebesar 1,898 dengan nilai signifikansi sebesar 0,068 yang dimana nilai Signifikansi ini lebih besar dari nilai pengambilan keputusan pada uji t yaitu sebesar 0,05. Dengan demikian hasil analisis regresi ini menunjukan bahwa Capital Adequacy Ratio di Bank Muamalat merupakan salah satu faktor yang tidak berpengaruh dalam Pembiayaan Murabahah.

Penelitian ini tidak mendukung penelitian Ferial Nurbaya pada tahun 2013 penelitian ini berjudul "Analisis Pengaruh CAR, ROA, FDR, dan Dana Pihak Ketiga (DPK) terhadap Pembiayaan Murabahah Periode Maret 2001 - Desember 2009”. Dari penelitiannya menyatakan bahwa CAR memiliki pengaruh yang positif dan signifikan terhadap Pembiayaan Murabahah.

Capital Adequacy Ratio merupakan rasio kinerja bank untuk mengukur kecukupan modal yang dimiliki bank untuk menunjang aktiva yang mengandung atau menghasilkan resiko. Yang berarti semakin tinggi nilai CAR maka semakin besar pula bank dapat menanggug resiko profitabilitasnya.

\section{Hasil Uji F (Uji Simultan)}

ANOVA ${ }^{b}$

\begin{tabular}{|l|l|l|l|l|l|} 
Model & Sum of Squares & df & Mean Square & F & Sig. \\
\hline
\end{tabular}


Volume 03 Nomor 012021 : page 49-63

p-ISSN: 2686-262X e-ISSN : 2685-9300

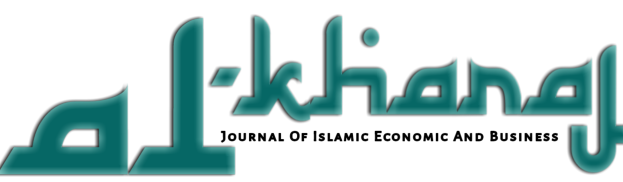

DOI : 10.24256

\begin{tabular}{|l|l|c|c|c|c|c|}
\hline \multirow{4}{*}{1} & Regression & 2011.213 & 3 & 670.404 & 18.306 & $.000^{\mathrm{a}}$ \\
\cline { 2 - 7 } & Residual & 988.787 & 27 & 36.622 & & \\
\cline { 2 - 7 } & Total & 3000.000 & 30 & & & \\
\hline
\end{tabular}

a. Predictors: (Constant), TCAR, TDPK, TSB

b. Dependent Variable: TPM Sumber: Hasil Uji SPSS, Tahun 2020.

Berdasarkan hasil uji F output SPSS pada tabel diatas, terlihat nilai F sebesar 18,306 dengan tingkat signifikansi sebesar 0,000. Dengan demikian nilai signifikansi lebih kecil dari 0,05 atau $5 \%(0,000<0,05)$. Jadi dapat disimpulkan bahwa variabel Suku Bunga $\left(\mathrm{X}_{1}\right)$, Dana Pihak Ketiga $\left(\mathrm{X}_{2}\right)$, dan Capital Adequacy Ratio $\left(\mathrm{X}_{3}\right)$ jika diuji secara bersama-sama berpengaruh secara signifikan terhadap Pembiayaan Murabahah.

\section{Hasil Uji Autokorelasi Model Summary}

\begin{tabular}{|c|c|c|c|c|c|}
\hline Model & $\mathrm{R}$ & $\mathrm{R}$ Square & $\begin{array}{c}\text { Adjusted R } \\
\text { Square }\end{array}$ & $\begin{array}{c}\text { Std. Error of the } \\
\text { Estimate }\end{array}$ & Durbin-Watson \\
\hline 1 & $.819^{\mathrm{a}}$ & .670 & .634 & 6.05159 & .501 \\
\hline
\end{tabular}

a.Predictors: (Constant), TCAR, TDPK, TSB

b.Dependent Variable: TPM

Sumber: Hasil Uji SPSS, Tahun 2020.

Hasil Uji Koefisien Determinasi $\left(\mathrm{R}^{2}\right)$ nilai Adjusted $\mathrm{R}$ Square pada penelitian ini yaitu sebesar 0,634. Hasil ini berarti 63,4\% variabel terikat Pembiayaan Murabahah dijelaskan oleh variabel bebas Suku Bunga, DPK, dan CAR pada penelitian ini. Sisanya 36,6\% dijelaskan oleh variabel lain diluar variabel yang digunakan. Jadi, sebagian besar variabel terikat dijelaskan oleh variabel-variabel yang digunakan dalam model penelitian ini.

\section{Kesimpulan dan Saran}

Berdasarkan hasil penelitian mengenai pengaruh Suku Bunga, Dana Pihak Ketiga, dan Capital adequacy Ratio terhadap Pembiayaan Murabahah pada bab sebelumnya, maka dapat ditarik kesimpulan sebagai berikut:

1. Berdasarkan hasil penelitian Suku Bunga yang telah dilakukan dengan menggunakan analisis regresi linear berganda mendapatkan hasil bahwa Suku Bunga tidak berpengaruh 
signifikan terhadap Pembiayaan Murabahah. Maka tinggi atau rendahnya nilai Suku Bunga tidak akan berdampak terhadap nilai Pembiayaan Murabahah. Sehingga, naik dan turunnya nilai Suku Bunga tidak dapat menjadi patokan atau tolak ukur naik dan turunnya nilai Pembiayaan Murabahah pada PT Bank Muamalat Indonesia Tbk Periode Maret 2012 sampai September 2019.

2. Berdasarkan hasil penelitian Dana Pihak Ketiga yang telah dilakukan dengan menggunakan analisis regresi linear berganda mendapatkan hasil bahwa Dana Pihak Ketiga berpengaruh positif dan berpengaruh signifikan terhadap Pembiayaan Murabahah. Maka tinggi atau rendahnya nilai Dana Pihak Ketiga akan berdampak terhadap nilai Pembiayaan Murabahah. Sehingga, naik dan turunnya nilai DPK akan menjadi patokan atau tolak ukur naik dan turunnya nilai Pembiayaan Murabahah pada PT Bank Muamalat Indonesia Tbk Periode Maret 2012 sampai September 2019.

3. Berdasarkan hasil penelitian Captal Adequacy Ratio yang telah dilakukan dengan menggunakan analisis regresi linear berganda mendapatkan hasil bahwa Captal Adequacy Ratio berpengaruh positif dan tidak berpengaruh signifikan terhadap Pembiayaan Murabahah. Maka tinggi atau rendahnya nilai Captal Adequacy Ratio tidak akan berdampak terhadap nilai Pembiayaan Murabahah. Sehingga, naik dan turunnya nilai Captal Adequacy Ratio tidak akan menjadi patokan atau tolak ukur naik dan turunnya nilai Pembiayaan Murabahah pada PT Bank Muamalat Indonesia Tbk Periode Maret 2012 sampai September 2019.

4. Berdasarkan hasil analisis uji $\mathrm{F}$ yang mendapatkan nilai $\mathrm{F}$ sebesar 18,306 dengan tingkat signifikansi sebesar 0,000. Dengan demikian nilai signifikansi lebih kuat dari 0,05 atau 5\%. Jadi variabel Suku Bunga $\left(\mathrm{X}_{1}\right)$, Dana Pihak Ketiga $\left(\mathrm{X}_{2}\right)$, dan Capital Adequacy Ratio $\left(\mathrm{X}_{3}\right)$ berpengaruh secara bersama- sama (simultan) terhadap Pembiayaan Murabahah. 
Sehingga saran yang dapat penulis berikan yaitu sebagai berikut:

1. Bagi Perbankan Syariah

Berdasarkan penelitian yang dilakukan terhadap pembiayaan Murabahah di Bank Umum Syariah khususnya pada PT Bank Muamalat Indonesia Tbk, maka Bank Muamalat harus terus melakukan inovasi baru dalam menciptakan pembiayaan berbasis jual beli dengan akad Murabahah. Sehingga dapat menghasilkan pendapatan yang ditargetkan melalui pembiayaan, seperti memiliki inovasi pada pengajuan pembiayaan dengan tingkat keuntungan (margin) yang lebih ringan dibanding dengan bank syariah lainnya. Bank Muamalat juga harus lebih meningkatkan penyaluran pembiayaan secara luas dalam hal usaha, agar dapat memperkokoh perusahaan dan meningkatkan perusahaan. Sehingga masyarakat lebih percaya dengan bank muamalat untuk mengelola dananya.

2. Bagi Peneliti Selanjutnya

Penelitian ini penulis menggunakan data laporan keuangan triwulanan periode Maret 2012 sampai September 2019. Menurut penulis penelitian ini akan lebih sempurna apabila data yang digunakan lebih banyak untuk mendukung penelitian ini. Maka ada baiknya jika peneliti selanjutnya, yang akan meneliti serupa dengan penelitian ini perlu melakukan penelitian dengan data yang lebih banyak. 


\section{DAFTAR PUSTAKA}

Adzimah, Rani Himmatul. (2017). Pengaruh Capital Adequacy Ratio (CAR) Dan Financing To Deposit Ratio (FDR) Terhadap Pembiayaan Murabahah Dengan Non Performing Financing (NPF) Sebagai Variabel Moderating, Skripsi, IAIN Salatiga.

Al-Mushih, A \& Shalah ash-Shawi. (2010). Fiqh Ekonomi Keuanan Islam. Jakarta: Darul Haq.

Andrianto, Didin F., \& Anang F. (2019). Manajemen Perbankan. Pasuruan: CV Penerbit Qiara Media.

Arifin, Johar. (2008). Statistik Bisnis Terapan dengan Microsoft Excel 2007. Jakarta: PT Elex Media Komputindo.

Arumdhani, Astri. (2012). Pengaruh Pembiayaan Murabahah dan Tingkat Suku Bunga BI terhadap Pendapatan Margin Murabahah pada PT Bank Syariah Mandiri Fakultas Ekonomi Universitas Komputer Indonesia,. Skripsi, Universitas Komputer Indonesia.

Badan Pusat Statistik. BI Rate, 2005-2020. Dalam https://www.bps.go.id/dynamictable/2015/12/22\%2000:00:00/1061/bi- rate-2005-2018.html. diakses pada 21 Maret 2020, pukul 10:45.

Bank Indonesia. BI 7 Day (Reverse) Repo Rate. Dalam https://www.bi.go.id/id/moneter/bi-7day- RR/penjelasan/Contents/Default.aspx. diakses pada 27 November 2019, pukul 14:22.

Bank Muamalat Indonesia Tbk. Laporan Triwulan. Dalam https://www.bankmuamalat.co.id/hubungan-investor/laporan-triwulan. Diakses pada 16 Maret 2020, pukul 10:38.

Bungin, Burhan. (2017). Metodologi Penelitian Kuantitatif. Jakarta: Kencana.

Dendawijaya, Lukman. (2010). Manajemen Perbankan. Jakarta: Ghalia Indonesia.

Djuwaini, Dimyauddin. (2008). Pengantar Fiqih Muamalah. Yogyakarta: Celebsn Timur UH III.

Faizatin, Naily. (2012). Belajar Mengenal Aritmetika. Jakarta: PT Balai Pustaka.

Ghozali, Imam. (2011). Aplikasi Analisis Multivariat Dengan Program IBM SPSS 19. Semarang: Badan Penerbit Universitas Diponegoro.

Gujarati, Demodar N. (2006). Dasar-Dasar Ekonometrika Jilid 2. Jakarta: Erlangga.

Hakim, Lukman. (2012). Prinsip-Prinsip Ekonomi Islam. Yogyakarta: Erlangga. Hamdi, A Saepul. (2014). Metodologi Penelitian Kuantitatif Aplikasi dalam Penelitian. Yogyakarta: Deepublish

Hasabuan, Malayu S.P. (2015). Dasar-dasar Perbankan. Jakarta: Bumi Aksara. Hasoloan, Jimmy. (2014). Ekonomi Moneter. Yogtakarta: Deepublish.

Ikit. (2015). Akuntansi Penghimpunan Dana Bank Syariah. Yogyakarta: Deepublish. 
Volume 03 Nomor 012021 : page 49-63

p-ISSN: 2686-262X e-ISSN : 2685-9300

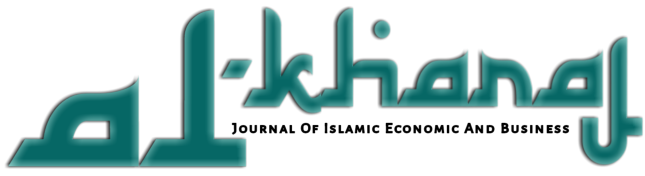

Ismail. (2010). Manajemen Perbankan: Dari Teori Menuju Aplikasi, .Jakarta:Kencana.

Ismail. (2011). Perbankan Syariah. Jakarta: Kencana.

Karim, A. (2013). Ekonomi Mikro Islami. Jakarta: Rajawali Pers.

Karim, Adimarwan A. (2011). Bank Islam: Analisis Fiqih dan Keuangan. Jakarta: Rajagrafindo Persada.

Kasmir. (2011). Dasar-dasar Perbankan. Jakarta: PT RajaGrafindo Persada.

Kasmir. (2012). Bank dan Lembaga Keuangan Lainnya, (Jakarta: PT Raja

Grafindo Persada.

Kasmir. (2015). Manajemen Perbankan. Jakarta: Raja Grafindo Persada.

Kuncoro, Mudrajad \& Suhardjono. (2011). Manajemen Perbankan: Teori dan Aplikasi. Yogyakarta: BPFE.

Loen, Boy,dkk. (2010). Manajemen Aktiva Pasiva Bank Devisa. Jakarta: Grasindo.

Machmud, A \& Rukmana. (2010) Bank syariah. Jakarta: Penerbit Erlangga.

Martono, Nanang. (2012). Metode Penelitian Kuantitatif Analisis Isi dan Analisis Data Sekunde. Jakarta: PT Raja Grafindo Persada.

Martono. (2010). Bank dan Lembaga Keuangan Lain. Yogyakarta: Ekonosia Fakultas Ekonomi Uii.

Muhammad. (2014). Manajemen Dana Bank Syariah. Yogyakarta: Rajawali Pers.

Nahrawi, Amirah Ahmad. (2017). Pengaruh Capital Adequacy Ratio (CAR), Return On Assets (ROA), dan Non Performing Financing (NPF) Terhadap Pembiayaan Murabahah BNI Syariah. Skripsi, Universitas Paramadina Jakarta.

Nurbaya, Ferial. (2013). Analisis Pengaruh CAR, ROA, FDR, dan Dana Pihak Ketiga (DPK) terhadap Pembiayaan Murabahah Periode Maret 2001 - Desember 2009. Skripsi, Universitas Diponegoro Semarang.

Nurhsanudin. (2017). Pengaruh Kompetisi, Capital Buffer, Diversifikasi Pendapatan dan Ukuran Bank terhadap Stabilitas Bank Syariah di Indonesia. Skripsi, Fakultas Ekonomi dan Bisnis Universitas Islam Negeri Syarif Hidayatullah Jakarta.

Pratiwi, Andita Dyar. (2019). Pengaruh Inflasi, BI 7 Day Repo Rate, Financing to Deposit Tario (FDR) dan Investasi terhadap Pembiayaan UMKM pada Bank Umum Syariah di Indonesia Fakultas Ekonomi dan Bisnis Islam IAIN Tulungagung. Skripsi, IAIN Tulungagung.

Priyanto, Dwi. (2012). Cara Kilat Belajar Analisis Data Dengan SPSS. Yogyakarta: CV Andi Offset.

Priyatno, Dwi. (2011). Buku Saku SPSS Analisis Statistik Data Lebih Cepat, Efisien dan Akurat. Yogyakarta:Mediakom. 
Rahman, Supandi. (2015). Pengaruh Tingkat Inflasi dan Suku Bunga Konvensional terhadap Pembiayaan Murabahah pada Bank Syariah di Indonesia Fakultas Ekonomi dan Bisnis Islam IAIN Sultan Amai Gorontalo. Skripsi, IAIN Sultan Amai Gorontalo.

Rahmani, Nur Ahmadi Bi. (2017). Analisis Pengaruh Capital Adequacy Ratio (CAR) dan Financing to Deposit Ratio (FDR) terhadap Return On Asset (ROA) dan Return On Equity (ROE) Pada Perusahaan Bank Umum Syariah di Indonesia. Human Falah Vol. 4 No. 2.

Riyadi, Selamet \& Rais Muhcamad Rafii. (2019). Pengaruh Dana Pihak Ketiga, Capital Adequacy Ratio, Bi Rate, Dan Financing To Deposit Ratio Terhadap Pembiayaan Murabahah Pada Bank Syariah Di Indonesia. Perbanas Review, Vol. 3, No. 2.

Ryad, Ahmad Muhammad \& Yupi Yuliawati. (2017). Pengaruh Dana Pihak Ketiga (DPK), Capital Adequacy Ratio (CAR), Non Performing Finance (NPF) Terhadap Pembiayaan. Jurnal Riset Akuntansi dan Keuangan Vol. 5 No. 3.

Sam, Ichwan. (2012). Himpunan Fatwa Dewan Syariah Nasional, Jakarta, Gaung Persada.

Santoso, Singgih. (2012). Latihan SPSS Statistik. Jakarta: Elekmedia Komputindo.

Setyani, Nining. (2019). Pengaruh Dana Pihak Ketiga, Modal, Inflasi dan BI 7- Days Repo Rate terhadap Profitabilitas pada PT Bank BNI Syariah Fakultas Ekonomi dan Bisnis Islam IAIN Tulungagung. Skripsi, IAIN Tulungagung.

Sjahdein, Sutan Remy. (2014). Perbankan syariah. Jakarta: Kencana Prenada Group.

Soemitro, Andri. (2009). Bank dan Lembaga Keuangan Syariah. Jakarta: Kencana Prenada Media Group.

Sugiyono. (2010). Statistik untuk Pendidikan. Bandung: Alfabeta.

Sunaryo. (2019). Manajemen Investasi dan Portofolio. Pasuruan: Qiara Media. Suryabrata, Sumadi. (2011). Metode Penelitian. Jakarta: Rajawali.

Sya'diyah, Mahmudatus. (2019). Fiqh Muamalah II Teori dan Praktik. Jepara: Unisnu Press.

Syeed, Abdullah. (2004). Menyoal Bank Syari"ah; Kritik Atas Interprestasi Bunga Kaum Neorevivalitas. Jakarta: Paramadina.

Unaradjan, Dominikus D. (2019). Metodologi Penelitian Kuantitatif. Jakarta: Universitas Katolik Indoneisa Atma Jaya.

Usanti, Trisadini P. (2016). Hukum Perbankan. Jakarta: Kencana.

Veithzal, Rivai \& Arviyan Arifin (2010). Islamic Banking. Jakarta: PT. Bumi Aksara.

Veithzal, Rivai \& Idroes (2007). Bank and financial institution managemant. Jakarta: Rajawali Pers. 
Wardiantika, Lifstin \& Rohmawati Kusumaningtias. (2014). Pengaruh DPK, CAR, NPF, Dan SWBI Terhadap Pembiayaan Murabahah Pada Bank Umum Syariah Tahun 2008201. Jurnal Ilmu Manajemen Vol. 2 No. 4.

Widanti, Annisaa Ligar. (2019). Pengaruh Dana Pihak Ketiga (DPK) dan BI 7 Days Repo Rate terhadap pembiayaan Murabahah pada PT. Bank BCA Syariah 2015-2017. Skripsi, UIN Gunung Djati Bandung. 